pregledni

naučni

članak

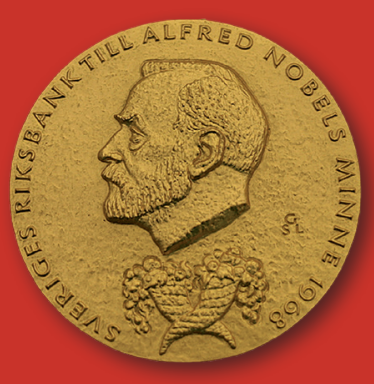

Svetlana Pantelić

Udruženje banaka Srbije svetlana.pantelic@ubs-asb.com
UDK 06.068NOBEL::331"2010" ; 331.5 Dejl Mortensen

\section{Dejl Mortensen}

Nobelova nagrada za 2010.

\section{DMP MODEL}

\section{Rezime}

U 2010. godini Nobelovu nagradu za oblast ekonomskih nauka dobio je Dejl Mortensen, rođen 1939. godine u Oregonu, SAD. Diplomirao je ekonomiju i matematiku, a doktorsku disertaciju odbranio na Nortvestern univerzitetu. Istraživačkim i profesorskim radom bavio se punih 47 godina, napisao brojne radove, autorske ili u saradnji sa drugim naučnicima. Osim njega, u toj godini Nobelovu nagradu su dobili i Piter Dajmond i Kristofer Pisarides, za doprinos analizi tržišta i poteškoćama usklađivanja ponude i tražnje, naročito pri zapošljavanju. Kreatori su modela DMP, nazvanom po prvim slovima njihovih prezimena. Danas je ovaj model analitičko sredstvo koje se najviše koristi za analizu nezaposlenosti, formiranja zarada i upražnjenih radnih mesta. Ovaj model se može koristiti i za procenu uticaja različitih faktora tržišta rada na nezaposlenost, plate i slobodna radna mesta.

Pomenuti nobelovci formulisali su teorijski okvir tržišta sa tražnjom. Dajmond je izvršio analizu osnova tih tržišta, Mortensn i Pisarides su proširili tu teoriju i primenili je na tržište rada. Model ovih laureata nam pomaže da shvatimo kako regulativa i ekonomska politika utiču na nezaposlenost, slobodna radna mesta i plate. To može da se odnosi na visinu beneficija $u$ okviru pomoći za nezaposlene ili propise vezane za zapošljavanje i otpuštanje. Jedan od zaključaka je da velikodušnije beneficije za nezaposlene rezultiraju višom stopom nezaposlenosti i dužim periodom traženja posla. Osim na tržištu rada, teorija tražnje može da se primenjuje u mnogim drugim oblastima, posebno na tržištu nekretnina.

Ključne reči: Nobelova nagrada, Piter Dajmond, Kristofer Pisarides, analiza, tržište, ponuda, tražnja, zapošljavanje, model DMP, tržište rada, nezaposlenost, plata, radna mesta

JEL: A13, B31, C78, E24, J64 


\section{scientific review article}

Dale T. Mortensen

Nobel Prize for 2010

\section{DMP MODEL}

\section{Summary}

In 2010 the Nobel Prize in Economic Sciences was awarded to Dale Mortensen, born in 1939 in Oregon, USA. He majored in economics and mathematics, and defended his doctoral dissertation at Northwestern University. He was a researcher and professor for full 47 years, having authored numerous papers, either by himself or in cooperation with other scientists. In addition to Mortensen, the 2010 Nobel Prize was also awarded to Peter Diamond and Christopher Pissarides for their contribution to the analysis of markets with search frictions, especially when it comes to employment. They created the DMP model, named after the first letters of their last names. Today this is an analytical instrument most used for analyzing unemployment, formation of wages and job vacancies. This model can be used to assess the impact of various factors of the labor market on unemployment, wages and job vacancies.

The concerned Nobel Prize winners formulated the theoretical framework for markets with search friction. Diamond performed the analysis of such markets' foundations; Mortensen and Pissarides expanded this theory and applied it on the labor market. The model designed by these laureates helps us realize how regulations and economic policy affect unemployment, job vacancies and wages. This may refer to the amount of unemployment benefits, or certain regulations in respect of hiring and dismissing people. One of the conclusions is that more generous benefits for unemployed people result in higher unemployment rates and longer job search. In addition to the labor market, the search friction theory may be applied in many other fields, especially at the real estate market.

Keywords: Nobel Prize, Peter Diamond, Christopher Pissarides, analysis, market, supply, demand, employment, DMP model, labor market, unemployment, wages, jobs 
U 2010. godini Švedska kraljevska akademija dodelila je Nobelovu nagradu za oblast ekonomskih nauka od 10 miliona švedskih kruna naučnicima: Piteru Dajmondu, Dejlu Mortensenu i Kristoferu Pisaridesu. Ovo priznanje dobili su za doprinos analizi tržišta i poteškoćama usklađivanja ponude i tražnje, naročito pri zapošljavanju. Kreatori su modela DMP, nazvanom po prvim slovima njihovih prezimena. Danas je ovaj model analitičko sredstvo koje se najviše koristi za analizu nezaposlenosti, formiranja zarada i upražnjenih radnih mesta. Ovaj model se može koristiti i za procenu uticaja različitih faktora tržišta rada na nezaposlenost, plate i slobodna radna mesta.

\section{Osnovne karakteristike nagrađenog izučavanja}

Prema objašnjenju Komiteta za dodelu Nobelove nagrade, ovi naučnici su razvili teoriju koja može da odgovori na pitanja zašto istovremeno ima toliko mnogo nezaposlenih, toliko mnogo slobodnih radnih mesta i kako ekonomska politika može da utiče na nezaposlene. Osim u slučaju tržišta rada, ta teorija je primenljiva

i na druga tržišta.

Na mnogim
tržištima kupci
i prodavci nisu
uvek u direktnom
kontaktu. To se
tiče između ostalog
prodavaca koji traže
zaposlene i radnike
u potrazi za poslom.
Budući da potraga
zahteva vreme i
resurse, to stvara
frikciju na tržištu.

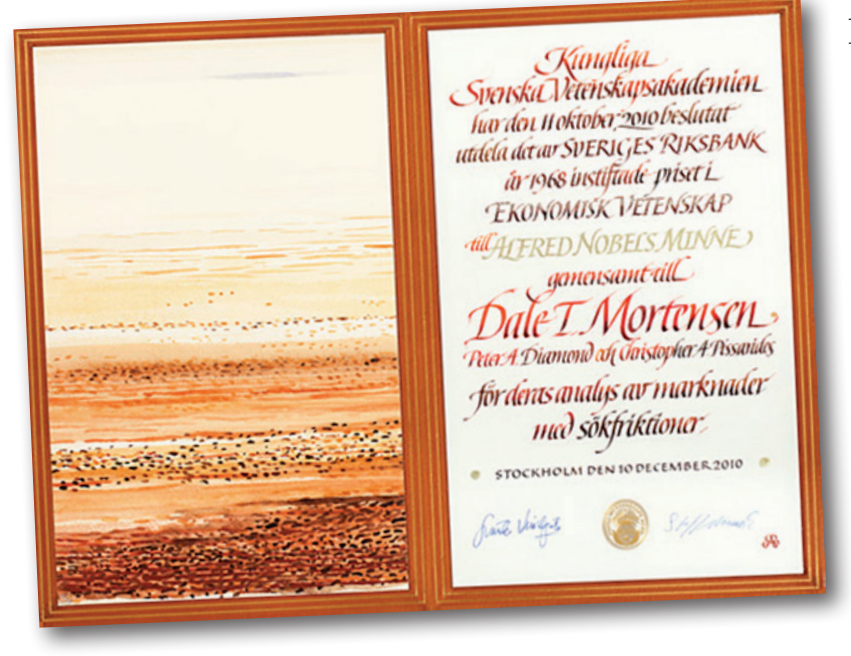

Na takvim tržištima će tražnja nekih kupaca ostati neispunjena, a neki prodavci neće prodati onoliko koliko budu želeli. Tako će na tržištu istovremeno postojati i nepopunjena radna mesta i nezaposlenost.

Nobelovci iz 2010. godine su formulisali teorijski okvir tržišta sa tražnjom. Dajmond je izvršio analizu osnova tih tržišta, Mortensen i Pisarides su proširili tu teoriju i primenili je na tržište rada.

Kako je istakao Nobelov Komitet, model ovih laureata nam pomaže da shvatimo kako regulativa i ekonomska politika utiču na nezaposlenost, slobodna radna mesta i plate. To može da se odnosi na visinu beneficija u okviru pomoći za nezaposlene ili propise vezane za zapošljavanje i otpuštanje. Jedan od zaključaka je da velikodušnije beneficije za nezaposlene rezultiraju višom stopom nezaposlenosti i dužim periodom traženja posla.

Osim na tržištu rada, teorija tražnje može da se primenjuje u mnogim drugim oblastima, posebno na tržištu nekretnina. Broj kuća na prodaju varira, kao i vreme potrebno da kuća nađe kupca i da se uključene strane dogovore o ceni. Teorija tražnje se takođe koristi za istraživanje monetarne teorije, ekonomije javnog sektora, finansijske, regionalne i porodične ekonomije.

\section{Školovanje}

Dejl Mortensen Tomas rodio se 2. februara 1939. godine u Oregonu. Majka Verna Eklund i otac Tomas Piter Mortensen su Danci po poreklu, čiji su se roditelji u Ameriku doselili iz ove zemlje. Očev prvi posao bio je u Šumarskoj službi jer je studirao šumarstvo i diplomirao na univerzitetu $\mathrm{u}$ Minesoti, dok je majka sa studijama stala nakon prve godine. $\mathrm{Za}$ vreme II svetskog rata odlaze u Portland, gde je otac radio $u$ brodogradilištu. Nakon rata preselili su se istočno od Portlanda u dolinu reke Hud gde se otac ponovo zaposlio u šumarskoj službi. Tada je to već bila višečlana porodica, Dejl je dobio još dva brata: Arnija i Irvinga.

Tokom školovanja hobi mu je bilo pevanje, gluma i fudbal, a za vreme raspusta pomagao je ocu na poslu. Bio je dobar đak koji je ispoljavao sklonost, ali i zainteresovanost za matematiku. Na poslednjoj godini srednje škole posebno se 
I n 2010 the Swedish Royal Academy awarded the Nobel Prize in Economic Sciences, in the amount of 10 million Swedish crowns, to the following scientists: Peter Diamond, Dale Mortensen and Christopher Pissarides. They won this award for their contribution to the analysis of markets with search frictions, especially when it comes to employment. They created the DMP model, named after the first letters of their last names. Today this is an analytical instrument most used for analyzing unemployment, formation of wages and job vacancies. This model can be used to assess the impact of various factors of the labor market on unemployment, wages and job vacancies.

\section{Main Characteristics of the Awarded Research}

According to the explanation of the Nobel Prize Committee, these scientists developed a theory that can provide answers to the question why there are so many unemployed people and so many job vacancies at the same time, and how economic policy may impact unemployment. In addition to the labor market, this theory is applicable to other markets as well.

On many markets, buyers and sellers are not always in the position to establish direct contact. Among others, this concerns the employers looking for employees, and workers looking for job. Given that this search requires time and resources, there occurs a search friction. On such markets, the demand of some buyers will remain unfulfilled, whereas some sellers will not sell as much as they wanted. This is how it happens that, at the same time, the market faces vacant jobs and

unemployment.

The 2010 Nobel Prize winners formulated the theoretical framework for markets with search friction. Diamond performed the analysis of such markets' foundations; Mortensen and Pissarides expanded this theory and applied it on the labor market.

As underlined by the Nobel Prize Committee, the model designed by these laureates helps us realize how regulations and economic policy affect unemployment, job vacancies and wages. This may refer to the amount of unemployment benefits, or certain regulations in respect of hiring and dismissing people. One of the conclusions is that more generous benefits for unemployed people result in higher unemployment rates and longer job search.

In addition to the labor market, the search friction theory may be applied in many other fields, especially at the real estate market. The number of houses for sale varies, as does the time required for a house to find its buyer, and for the involved parties to agree on the price. The search friction theory is also used to investigate monetary theory, economics of the public sector, financial economics, regional and family economics.

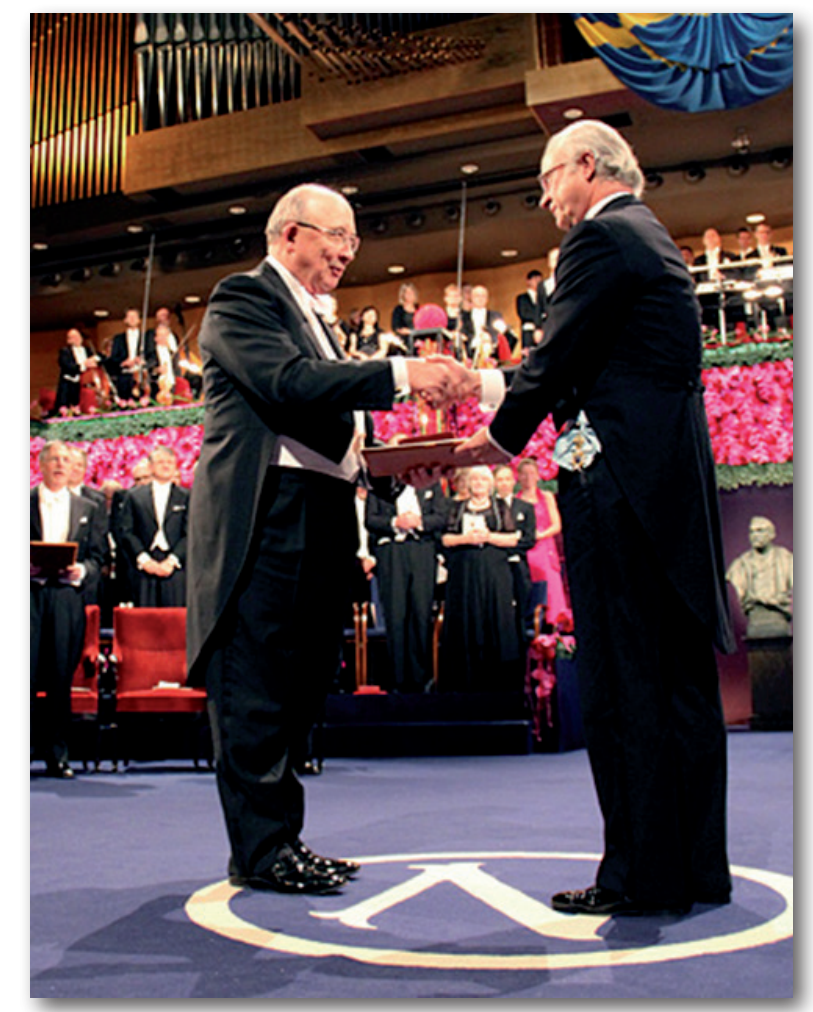

Dejl Mortensen prima nagradu od švedskog kralja Karla Gustava XVI, 10. decembra 2010. godine

Dale T. Mortensen receiving his Prize from His Majesty King Carl XVI Gustaf of Sweden at the Stockholm Concert Hall, 10 December 2010

\section{Schooling}

Dale Mortensen Thomas was born on 2 February 1939 in Oregon. His mother, Verna Ecklund, and his father, Thomas Peter Mortensen, were of Danish origin, their parents having immigrated into the US from Denmark. His father's first job was at the US Forest Service, given that he graduated from the School of Forestry at the University of Minnesota, whereas his mother quit her studies after the first year. During the 


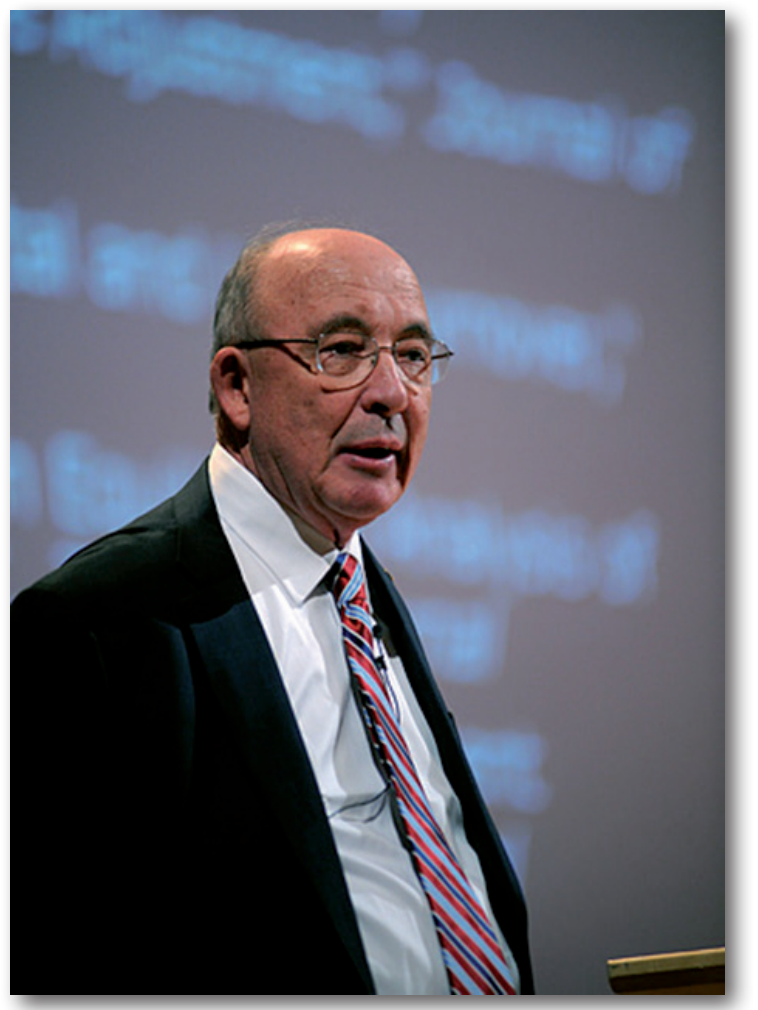

zainteresovao za američku društvenu istoriju krajem 19. i početkom 20. veka. Odnosno, postao je zabrinut za proces industrijalizacije i njen uticaj na transformaciju zemlje. Osim toga, još mnogo ranije bio je suočen i sa dilemama koje su vezane za socijalna pitanja. U biblioteci je igrom slučaja otkrio Teoriju igara i ekonomskog ponašanja autora Fon Nojmana i Morgensterna. Njihova izučavanja su mu dala odgovor na to šta predstavlja teorija igara i kako se matematika može koristiti u društvenoj analizi.

Upisao se na Vilamet (Willamette) jer je od njih dobio punu stipendiju. Diplomirao je ekonomiju i matematiku i postao asistent profesoru Ričardu Gilisu. Za postdiplomske studije izabrao je Karnegi institut za tehnologiju iz Pitsburga zbog stipendije, ali i zbog analitičkog i interdisciplinarnog pristupa u proučavanju ekonomije i menadžmenta. U ovaj grad je došao 1961. godine i zainteresovao se za izučavanja tradicionalne ekonomije, posebno teorije rasta koju je počeo Majkl Lovel, sin njegovog omiljenog profesora istorije sa Vilameta. U ovom periodu je upoznao Beverli Peton, kako sam ističe "ljubav svog života". Venčali su se 1963. godine i ubrzo je postao otac troje dece: Karla, Lije i Džuli. Tada je počeo, ali i završio svoju doktorsku tezu. Karnegi institut za tehnologiju bio je izuzetno mesto u to vreme, u kojem su se rađale mnoge nove ideje zbog kojih su često studenti prisustvovali žučnim i interesantnim debatama među profesorima. Takođe, studenti su ohrabrivani da se uključe $\mathrm{u}$ procese istraživanja i pored toga što nisu $\mathrm{u}$ potpunosti ovladali znanjem iz tih oblasti koje su predmet izučavanja.

Postao je član Univerziteta Nortvestern 1965. godine. U prvim godinama rada zahvaljujući pomoći dva buduća nobelovca Hiksa (1972) i Semjuelsona (1970) naučio je osnove ekonomske analize i razvio nastavne veštine. Tih godina odbranio je i doktorsku disertaciju na Karnegi Melon univerzitetu, što je bio novi naziv za Karnegi institut za tehnologiju. Za Dejla ovo su bile teške godine rada sa studentima, pripreme doktorske disertacije i brige za tri bebe, odnosno svoje troje dece. Najveću zahvalnost, kako sam ističe, najviše duguje svojoj supruzi, njenom strpljenju, istrajnosti i ljubavi, bez koje u svemu tome ne bi uspeo.

U novom okruženju Dejlu su se promenila i interesovanja u ekonomiji. Tome su doprinele i nove kolege koji su došle na ovaj fakultet: Frenk Brehling koji je istraživao dinamiku tržišta rada i Art Tredvej koji je razvijao modele troškova prilagođavanja i radio na njihovoj primeni $\mathrm{u}$ teoriji investicija. Njima se pridružio i Bernt

\section{Autorski radovi}

Dejl Mortensen je u svojoj dugoj i plodnoj profesorskoj i istraživačkoj karijeri napisao brojna dela sam ili u saradnji sa drugim naučnicima, od toga preko 50 naučnih članaka.

1. D. Mortensen (2005), Disperzija zarade: Zašto su slični radnici plaćeni drugačije? , MIT Press.

2. D. Mortensen (1986), 'Potraga za poslom i analiza tržišta rada'. Poglavlje 15 u Priručniku ekonomije rada, vol. 2, O. Ašenfelter i R. Lajard, ur., North-Holland.

3. D. Mortensen (1982), 'Proces mapiranja kao nekooperativna igra/igra cenkanja'. $\mathrm{U}$ : Ekonomija informacija i neizvesnosti, Dž. MekKol, ur., NBER.

4. D. Mortensen (1972), 'Teorija dinamike zarada i zaposlenosti', U: Mikroekonomske osnove teorije zaposlenja $i$ inflacije, E. Felps et al., ur., Norton. 
World War II they left for Portland, where Dale's father worked in a shipbuilding factory. After the war, they moved the Hood River Valley east of Portland where his father returned to the practice of forestry. By that time, the family had gained new members, and Dale two brothers: Arne and Irving.

During his high school years, he was interested in singing, acting and football, and on holidays he would assist his father at work. He was a good student, expressing an ability and interest in mathematics. In his final year at high school, he developed a particular interest in the American social history of the late 19th and early 20th centuries, i.e. he became concerned about the process of industrialization and its impact on the transformation of the country. Although it was much earlier that he faced the dilemmas regarding social issues. By chance, he found at the library The Theory of Games and Economic Behavior by von Neumann and Morgenstern. Their investigations gave him an answer to what game theory is, and how he could apply mathematics to social analysis.

He enrolled at Willamette as the beneficiary of a full scholarship. He majored in economics and mathematics and became a senior assistant

\section{Selected Works}

In his long and fruitful career as a professor and researcher, Dale Mortensen authored numerous works, either by himself or in cooperation with other scientists, over 50 of which are categorized as scientific papers.

1. D. Mortensen (2005), Wage Dispersion: Why Are Similar Workers Paid Differently?, MIT Press.

2. D. Mortensen (1986), 'Job search and labor market analysis'. Ch. 15 of Handbook of Labor Economics, vol. 2, O. Ashenfelter and R. Layard, eds., North-Holland.

3. D. Mortensen (1982), 'The matching process as a non-cooperative/bargaining game'. In The Economics of Information and Uncertainty, J. McCall, ed., NBER.

4. D. Mortensen (1972), 'A theory of wage and employment dynamics.' In Microeconomic Foundations of Employment and Inflation Theory, E. Phelps et al., eds., Norton.

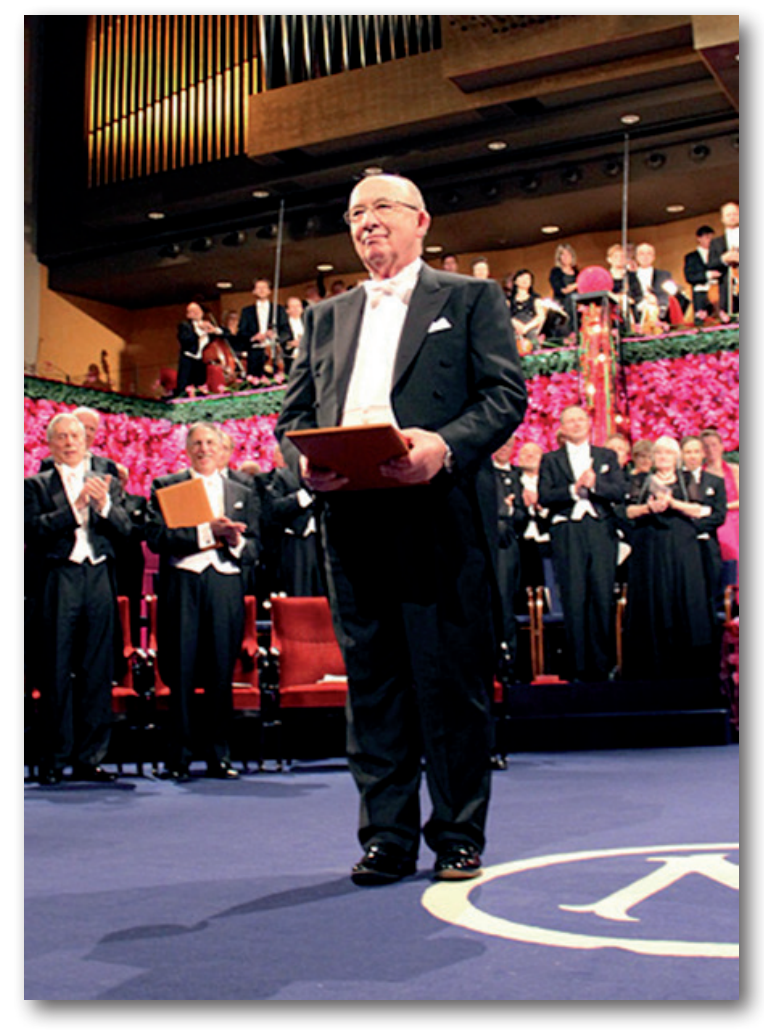

to Professor Richard Gillis. For his postgraduate studies, Mortensen chose Carnegie Institute of Technology in Pittsburgh, due to its generous fellowship, but also due to its innovative program that emphasized an analytic as well as interdisciplinary approach to the study of economics and management. He came to Pittsburgh in 1961, and turned to more traditional economics, especially growth theory, originated by Michael Lovell, son of his favorite history professor at Willamette. It was in this period that he met Beverly Patton, "the love of his life". They were married in 1963 and soon became the proud parents of three children, Karl, Lia and Julie. Along the way, he started and completed his doctoral thesis. Carnegie Tech was an amazing place at the time, with new ideas of all kinds always in the air, which is why the students frequently witnessed the lively debates among the faculty. Moreover, the students were encouraged to get involved in the research process even before they had mastered the details of the relevant literature.

Mortensen became a member of the faculty at Northwestern University in 1965. In his first years of work, he finally learned the foundations of economic analysis and developed his teaching skills, thanks to the assistance of two future Nobel Prize winners, Hicks (1972) and Samuelson (1970). In those years he defended 
Stigam koji je radio i na analizi vremenskih serija i na teoriji dinamične opšte ravnoteže. Zajedno su postali stručnjaci za teoriju kontrole i dinamičko programiranje.

Sredinom šezdesetih vodile su se žučne debate oko Filipsove krive i njene implikacije na ekonomsku politiku. Kao što je poznato, Filipsova kriva je u ekonomiji negativni statistički odnos između stope inflacije i stope nezaposlenosti. Odnosno, što je stopa nezaposlenosti u ekonomiji neke države niža, to je veća stopa promene $\mathrm{u}$ platama radne snage ekonomije te države. Na Nortvesternu stvorena je neformalna grupa koju su, pre svega, činili Brehling, Tredvej i Kris Arčibald. Uz njihovu pomoć Dejl je počeo da razmišlja o karakteristikama decentralizovanog tržišta. Priredio je članak namenjen formulisanju i razradi nekih ideja $u$ vezi sa tržištem rada. Tokom svog boravka na Nortvesternu radi seminara 1968. godine, Edmund Felps iz Londona obavestio je Dejla da je sa zanimanjem pročitao njegov rad, kao i druge materijale istraživača sličnog područja. Tom prilikom ga je pozvao na planiranu konferenciju o ovoj temi na Univerzitetu Pensilvanija. Dejlov rad objavljen je u zborniku radova koji su predstavljeni na ovoj konferenciji.

\section{Dejlov recept za uspešnost}

Iako se Felps, Robert Lukasi Dejl, svi dobitnici Nobelove nagrade, nisu uvek slagali po pitanju detalja, te išli različitim pravcima ka cilju, delili su zajednički stav da je makroekonomiji neophodan temelj $\mathrm{u}$ vidu analize ravnoteže tržišta koja se zasniva na principu da agenti na takvim tržištima deluju u sopstvenom interesu. Dejlov rad iz 1970. godine: "Potraga za poslom, period trajanja nezaposlenosti i Filipsova kriva" ("Job Search, the Duration of Unemployment and the Phillips Curve"), objavljen u American Economic Review, bio je pokušaj da se na primeru protumači Filipsova kriva. Autor smatra da on u toj dimenziji nije dao neki značajan diprinos. Stvarni doprinos ovog autorskog rada zajedno sa radom Džona MekKola, koji je objavljen u isto vreme, predstavljao je novi model dinamičnog pristupa razumevanju nezaposlenosti.

Mortensenovi stavovi nisu naišli na jedinstveno prihvatanje, jer, kada je svoj model prikazao na sastanku Američkog udruženja ekonomista, neki od prisutnih su napustili ovaj godišnji skup u znak protesta i neslaganja. No i pored toga, njegove kolege iz Nortvesterna su ga izabrale za vanrednog profesora.

Školsku 1970-71. zajedno sa porodicom proveo je kao gostujući profesor na Univerzitetu u Eseksu, Engleska. U to vreme zajedno sa Frenkom Brehlingom radio je na projektu dizajniranja i formulisanja modela procene dinamike zapošljavanja koja je zasnovana na ideji da je regrutovanje i zapošljavanje radnika proces koji zahteva vreme i resurse. Napisao je i rad "Generalizovani troškovi prilagođavanja i teorije tražnje sa dinamičkim faktorom" ("Generalized Costs of Adjustment and Dynamic Factor Demand Theory") koji

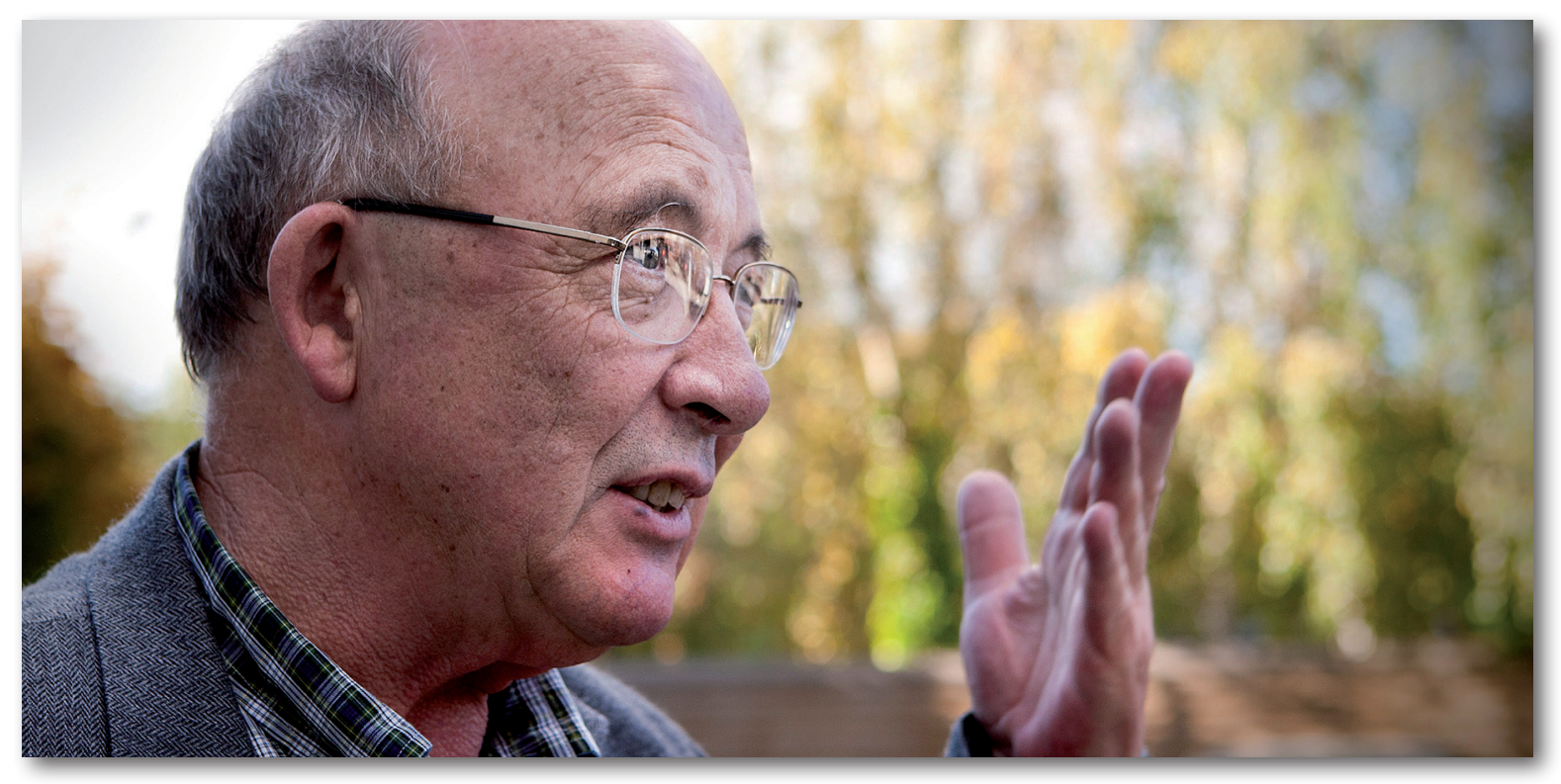




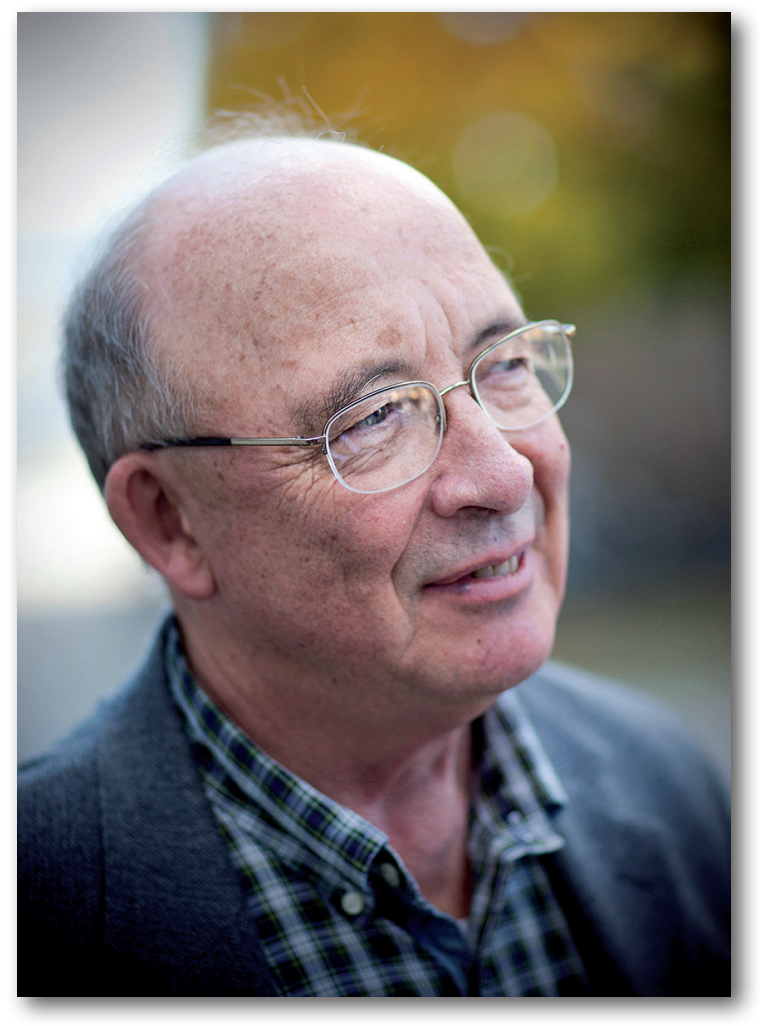

his doctoral dissertation at Carnegie-Mellon University, which was the new name for the Carnegie Institute of Technology. For Dale, these were rather difficult years, taking into account his teaching, the work on his thesis, and helping care for three babies. Without the patience and perseverance of a loving wife, as he himself underlined, he would not have succeeded.

Dale's interests in economics changed in this new environment. Two new and important colleagues arrived, Frank Brechling, whose research was focused on the dynamics of the labor market and Art Treadway, who was developing costs of adjustment models and applying them to investment theory. They were joined by Bernt Stigum who was doing work on both time series analysis and dynamic general equilibrium. Together, they became proficient in control theory as well as dynamic programming.

In the mid-1960s a debate raged over the Phillips curve and its implications for economic policy. As already known, the Phillips curve in economics is a negative statistical association between the inflation rate and the unemployment rate. In other words, the lower the unemployment rate in a country's economy, the higher the volatility of wages paid to the labor force of that country's economy. An informal group was formed at Northwestern, gathering, in the first place, Brechling, Treadway and Chris Archibald. With their help, Mortensen began to think about how to capture the essential features of a decentralized market. He wrote a working paper designed to formulate and work out some of these ideas concerning the labor market. Edmund Phelps came from London to Northwestern to give a seminar in the fall of 1968, and informed Dale that he had read his paper with interest, along with the other materials prepared by researchers in the similar fields. On that occasion, he invited him to the conference he had planned on this topic at the University of Pennsylvania. Dale's paper was published in the collection of papers presented at this conference.

\section{Dale's Formula for Success}

Although Phelps, Robert Lucas and Dale, all of them Nobel laureates, not always agreed on the details and took different direction in the pursuit of the goal, they shared a common view that macroeconomics needs a foundation in equilibrium market analysis based on the principle that agents in such markets act in their own self interest. Dale's paper "Job Search, the Duration of Unemployment and the Phillips Curve", published in 1970 in the American Economic Review, was an attempt to interpret the Phillips curve by means of an example. The author, however, believes that in this dimension he failed to give a substantial contribution. The actual contribution of this paper, along with those of John McCall, published at about the same time, was the new model of a dynamic approach to the understanding of unemployment.

Mortensen's views were not met with undivided acceptance, and when he presented his model at the annual meeting of the American Economic Association, some who attended walked out in protest. Nevertheless, his colleagues at Northwestern chose to promote him to Associate Professor.

Together with his family, Mortensen spent the academic year 1970-71 on sabbatical visiting at the University of Essex in England. At the time Frank Brechling and Dale were working together on a project designed to 
obezbeđuje matematičku osnovu za ulaganja u proizvoljan broj kapitalnih dobara.

Avgusta 1982. godine Dejl Mortensen pozvan je zajedno sa Kenom Burdetom, Džordžom Nojmanom i Nikolasom Kiferom da prisustvuje prvoj konferenciji na ovu temu u kongresnom centru Sandbjerg Manor, na jugu Jilanda u vlasništvu Univerziteta Arhus. Učešće na ovom skupu bilo je rezultat primene analize tržišta rada u više zemalja.

U ranim osamdesetim Piter Dajmond i Dejl Mortensen izdefinisali su model dvostrane pretrage i podudarne ravnoteže. Njihovi radovi su inkorporirali koncept odgovarajućih funkcija i pretpostavke da se plate određuju kroz bilateralne pregovore. Nakon pojave ovih njihovih radova, Kristofer Pisarides je završio svoja istraživanja koja su postala poznata pod imenom DMP model tržišta rada. U narednim izučavanjima Dejl je sa Krisom istraživao implikacije modela za širok spektar vladinih politika, uključujući i zaštitu zaposlenja. Otkrili su da je njihov model odlično detektovao glavne efekte ograničenja otpuštanja radnika, koji se reflektuju u smanjenom tipičnom protoku radnika iz radnog odnosa do nezaposlenosti i od nezaposlenosti do zaposlenja. Prema ovom modelu, privrede koje imaju nefleksibilno tržište rada iskusile su u poslednjih 30 godina probleme prilagođavanja promenama $\mathrm{u}$ tehnologiji.

I nakon ovih istraživanja Dejl je nastavio sa novim izučavanjima sam ili sa svojim kolegama, profesorima i saradnicima. Osim toga, nastavio je i sa predavanjima na mnogim univerzitetima: Univerzitetu u Eseksu, Univerzitetu Kornel, Kalifornijskom institutu za tehnologiju, Univerzitetu u Njujorku, Univerzitetu Arhus, Univerzitetu Nortvestern. U vreme kada mu je dodeljena Nobelova nagrada, Mortensen je bio redovni profesor na Univerzitetu Nortvestern. Preminuo je nedavno, 9. januara 2014. godine.

Na osnovu izjava kolega i saradnika po dobijanju Nobelove nagrade očigledno je da je Mortensen omiljen na fakultetu, među profesorima i studentima. Džoel Mokir, profesor na Nortvesternu, ovako je ukratko opisao Dejla: "On je divan kolega i veliki čovek. Njegov rad je bio prosto neverovatan i objašnjava mnogo o tome zašto u svakom trenutku ima mnogo ljudi koji ne rade. Daje nam veoma bogatu i korisnu teoriju nezaposlenosti koja se veoma razlikuje od našeg poimanja nezaposlenosti".

Dejl je u svojoj biografiji za sajt posvećen nobelovcima istakao da je stara izreka "Iza svakog uspešnog čoveka stoji uspešna žena" potvrđena u njegovom slučaju. Oženio je Beverli još u studentskim danima, četiri godine kasnije imao je doktorat i troje dece. Beverli se u braku aktivno bavila muzikom, naročito komponovanjem. Izveli su decu na put, svi su završili fakultete i od njih imaju osam unučadi. Dejlova supruga se vratila na fakultet kada su im deca završila studije, doktorirala i zaposlila se kao profesor.

Prijatelji Dejla Mortensena su ga često pitali kako je uspeo da 45 godina ima isti posao i 47 godina istu ženu. On je za njih imao jednostavan odgovor: "U oba slučaja napravio sam odličan izbor!"

\section{Literatura / References}

1. "Dale T. Mortensen - Facts". Nobelprize. org. Nobel Media AB 2013. Web. 9 Jun 2014. <http://www.nobelprize.org/nobel_ prizes/economic-sciences/laureates/2010/ mortensen-facts.html>

2. Petrović Vesna, Nobelova nagrada - prestiž u svijetu nauke - izazovi savremene ekonomije, Ekonomist, br. 8, Univerzitet u Istočnom Sarajevu, Fakultet poslovne ekonomije, Bijeljina

3. Dale Mortensen, Nobel Laureate, Dies AT 78, Nortwestern University

4. The Daily Nortwestern, Nortwestern remembers economics professor Dale Mortensen in memoral service 


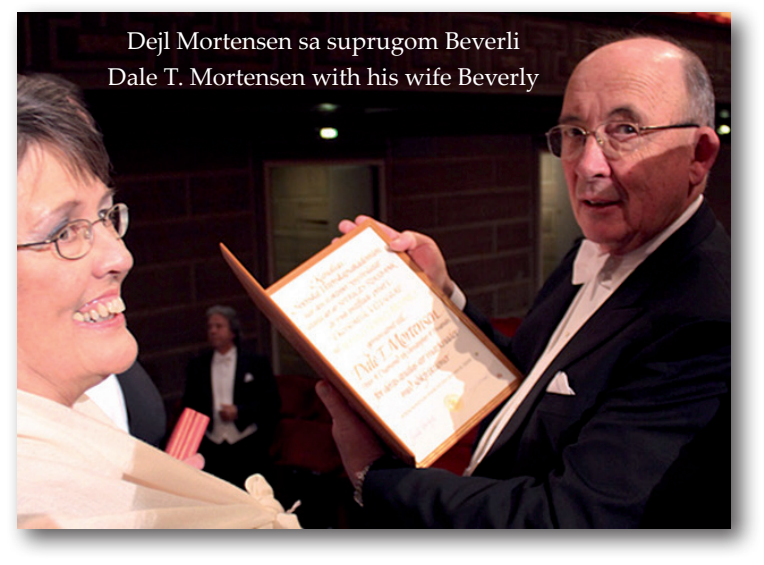

formulate and estimate a model of employment dynamics based on the idea that the process of recruiting and hiring workers was a time and resource consuming process. As part of that project, he wrote a paper "Generalized Costs of Adjustment and Dynamic Factor Demand Theory", which provided a mathematical foundation for investment in an arbitrary number of capital goods.

In August 1982, together with Ken Burdett, George Neumann and Nicholas Kiefer, Mortensen was invited to attend the first conference featuring these data held at Sandbjerg Manor, a convention center in the south of Jutland, owned by Aarhus University. The participation at this conference came as a result of the implementation of labor market analysis in several countries.

In the early 80s, Peter Diamond and Dale Mortensen were both creating models of two sided search and matching equilibrium. These papers incorporated the concept of a matching function and assumed that wages were determined through bilateral bargaining. Shortly after the appearance of these papers, Christopher Pissarides completed what became known at the Diamond-Mortensen-Pissarides or DMP model of the labor market. In a subsequent series of co-authored papers, Chris and Dale also investigated the implications of the model for a wide variety of government policies including employment protection. They found that their model did a good job of capturing the principal effects of firing restrictions, a reduction in both the typical flow of workers from employment to unemployment and from unemployment to employment. According to the model, economies with labor market inflexibilities of this kind have problems adjusting to the changes in technology experienced in the last thirty years.

Following these investigations, Dale continued his research either alone or in cooperation with his colleagues, professors and associates. Besides, he continued to teach at many universities: University of Essex, Cornell University, California Institute of Technology, University of New York, Aarhus University, and Northwestern University. At the time he received the Nobel Prize, Mortensen was a full-time professor at Northwestern. He passed away recently, on 9 January 2014.

Judging from the statements of his colleagues and associates after Mortensen won the Nobel Prize, he was obviously beloved at the university, both among the professors and among the students. Joel Mokyr, Professor at Northwestern, described Dale in a few words: "He is a wonderful colleague and a great human being, and his work has been absolutely pathbreaking. He explains a great deal about why at any given point in time there are a lot of people who are not working, and he gives a very rich and extremely useful theory of unemployment that's very different from our normal ideas of unemployment."

As Dale himself underlined in his biography, written for the Nobel Prize winners website, the old saying that "behind every great man there is a great woman" perfectly fits his case. He married Beverly while they were both students. Four years later, he had three children and his $\mathrm{PhD}$ degree. Later on, Beverly was actively engaged in music, especially composing. They raised their children successfully, all of them graduated from universities, and endowed them with eight grandchildren. Dale's wife returned to college after their children had graduated, obtained her own PhD degree, and started teaching as a professor.

The friends of Dale Mortensen often asked him how it is that he has had the same job for 45 years and the same wife for 47 . His response was simple: "Both are excellent matches!" 